\title{
Characteristics of fiscal policy in Croatia: does it depend on the phase of the business cycle?
}

VLADIMIR ARČABIĆ, Ph.D.*
FRANE BANIĆ, MA*

Article $^{* *}$

JEL: E62, H62, H63, E32, C24

https://doi.org/10.3326/pse.45.4.3

\footnotetext{
* This paper has been partially supported by Croatian Science Foundation under projects IP-2019-04-4500 and UIP-2017-05-6785. The views expressed in this paper are not necessarily the views of the Croatian National Bank. The authors would like to thank two anonymous referees for their useful comments and suggestions. ${ }^{* *}$ Received: July 1, 2021

Accepted: September 20, 2021
}

\section{Vladimir ARČABIĆ}

University of Zagreb, Faculty of Economics and Business, Trg J. F. Kennedyja 6, 10000 Zagreb, Croatia e-mail: varcabic@efzg.hr

ORCiD: 0000-0003-4173-8637

Frane BANIĆ

Croatian National Bank, Trg hrvatskih velikana 3, 10000 Zagreb, Croatia

University of Zagreb, Faculty of Economics and Business, Trg J. F. Kennedyja 6, 10000 Zagreb, Croatia, Ph.D. student

e-mail: frane.banic@hnb.hr

ORCiD: 0000-0002-1672-931X 


\section{Abstract}

This paper analyzes fiscal policy sustainability and cyclicality in Croatia. The main novelty of the paper is that our fiscal response function allows for asymmetric behavior over the business cycle. We allow fiscal policy sustainability and cyclicality to differ across the expansionary and recessionary regimes. The overall results suggest that fiscal policy in Croatia is both sustainable and countercyclical. We find evidence of asymmetric behavior of fiscal policy cyclicality. In the expansionary regime, fiscal policy is countercyclical, while in the recessionary regime, it varies between procyclical and acyclical. On the other hand, we find only limited evidence of asymmetric behavior of public debt sustainability. During good times, Croatian policymakers try to keep fiscal policy both sustainable and countercyclical, which is required fiscal policy behavior. In recessionary times, the characteristics of fiscal policy are not so clear, but tend to be procyclical or acyclical.

Keywords: fiscal policy, sustainability, cyclicality, uncertainty, public debt, nonlinear models

\section{INTRODUCTION}

Given the adverse effects of the global financial crisis (GFC) on the economy and public finances, the possibilities and limitations of fiscal policy become an important research question, especially its sustainability and cyclicality. Many countries recorded unfavorable fiscal indicators in the aftermath of the GFC, including Croatia. Shortly after Croatia's accession to the European Union (EU) in 2013, an excessive deficit procedure (EDP) was launched in 2014 and abrogated in 2017 by a council decision based on a recommendation by the Commission due to noncompliance with Treaty reference values. During that period, the excessive deficit in Croatia was corrected: the general government deficit-GDP ratio dipped below $3 \%$, and the public debt-GDP ratio was stabilized.

Although it is noticeable that fiscal policy was stabilized in the period from 2014 to 2017, questions of the extent to which fiscal policy is sustainable and the nature of its behavior during the business cycle arise. The aim of the paper, then, is to analyze fiscal policy sustainability and cyclicality. Strengthening fiscal discipline and consequently creating fiscal space to alleviate the adverse effects of the crisis on fiscal indicators should be the main focus of fiscal policymakers. Information on fiscal policy behavior and public debt sustainability in Croatia is very important for fiscal policymakers in relation to accession to the euro area, given the fiscal convergence criteria.

This paper analyzes public debt sustainability and fiscal policy cyclicality using Bohn's (1998) fiscal reaction function. The main point of the paper is that we analyze fiscal policy characteristics over different phases of the business cycle, e.g., expansions and recessions. Therefore, we study the asymmetric behavior of fiscal policy, allowing for different behavior depending on the business cycle phase. Public debt sustainability tells us how policymakers react to indebtedness. 
Public debt is considered sustainable when the primary balance increases as a response to higher indebtedness. On the other hand, fiscal policy cyclicality tells us whether fiscal policy behaves pro or countercyclically. Countercyclical fiscal policy is preferred as it smooths business cycles.

To analyze the asymmetric behavior of fiscal policy over the business cycle, we estimate Bohn's (1998) fiscal reaction function using two nonlinear models, e.g., threshold regressions and the Markov switching model. The nonlinear models allow for an endogenous switch depending on the output gap, which defines different regimes. Then, the estimated coefficients differ across the regimes. The upper and lower regime could be related to periods of expansion and recession, respectively. Consequently, the analysis is focused on potential asymmetric effects from the aspect of fiscal policy cyclicality and public debt sustainability.

We take business cycle measurement seriously and use two univariate output gap measures (Hamilton, 2018; Hodrick and Prescott, 1997) and one bivariate measure based on the structural vector autoregressive model (SVAR). All three measures are used both for output gap and cyclically adjusted primary balance (CAPB) calculation; regarding the character of fiscal policy, that is, it is more appropriate to use a cyclically adjusted primary balance instead of the primary balance. Then, the effect of the cycle on the budget is removed, and consequently, the problem of endogeneity is avoided. Also, the cyclically adjusted primary balance provides information on the discretionary measures of fiscal policymakers, which directly determine the behavior of fiscal policy.

In our analysis, Bohn's (1998) fiscal reaction function is extended with lagged cyclically adjusted primary balance and with the growth rate of the economic policy uncertainty index (EPU index) in the robustness check. The EPU index was applied given the assumed impact of uncertainty on the discretionary measures of fiscal policymakers.

Our findings indicate the public debt sustainability and the countercyclical behavior of fiscal policy in Croatia. We find stronger evidence of asymmetry in fiscal policy cyclicality than of public debt sustainability. In other words, fiscal policy cyclicality changes over the business cycle, typically switching from countercyclical in the upper regime (expansions) to acyclical in the lower regime (recessions). Controlling the models for economic policy uncertainty does not change the results substantially.

The paper is divided into five sections. The next section presents a literature review and discusses empirical research in the context of fiscal policy cyclicality and public debt sustainability. The third section describes the construction of variables applied in the analysis and the research methodology. The fourth section presents the results on the asymmetry of fiscal policy behavior and public debt sustainability, more specifically, the results of rolling regressions, linear and nonlinear models, while the fifth section presents concluding remarks. 
In empirical research, fiscal sustainability is mostly assessed using the fiscal response function initially proposed by Bohn (1998). The economic intuition of the fiscal response function is twofold. First, it provides information on the cyclical nature of fiscal policy, i.e., procyclical or countercyclical behavior, and second, it provides information on public debt sustainability.

Most empirical research indicated the existence of a fiscal response function, i.e., empirical confirmation of the positive relationship between the budget or primary balance and lagged public debt (Berti et al., 2016; Cassou, Shadmani and Vázquez, 2017; Piergallini and Postigliola, 2012; Checherita-Westphal and Žd'árek, 2017; Banić, 2020). In other words, an increase in public debt will result in an increase in the budget or primary balance in order to mitigate the negative impact of public debt accumulation on the sustainable management of public finances. Such a response is considered to reflect sustainable fiscal policy. Checherita-Westphal and Žd'árek (2017) assessed the function of the fiscal response in the European Union using a dynamic panel analysis for the period from 1970 to 2013. Furthermore, the primary balance to GDP ratio represents a function of the lagged public debt GDP ratio, control variables, i.e., lagged primary balance to GDP ratio, and certain institutional and political factors. The results of the panel analysis indicate a positive reaction of fiscal policymakers, i.e., an increase in the primary balance by about $0.03-0.05 \%$ when the share of public debt in GDP increases by one percentage point. Berti et al. (2017) assessed the fiscal response function on a sample of twelve Central and Eastern European countries in the period from the mid-1990s to 2013. In an empirical study, they applied various methods of static (pooled ordinary least squares (OLS) and panel model with fixed effects) and dynamic (generalized method of moments, GMM) panel analysis for the purpose of checking the robustness of the model, where the primary balance is defined as a function of the lagged primary balance, lagged public debt, expenditure gap and inflation. Regardless of the chosen method, all the obtained results indicated a statistically significant and positive relationship between the primary balance and lagged public debt. Piergallini and Postigliola (2012) analyzed public debt sustainability in Italy, assessing the function of the fiscal response in the period from 1861 to 2009. The results of the estimated vector autoregression (VAR) model indicate the positive fiscal response in Italy, emphasizing the fiscal policymakers' awareness of the negative consequences of public debt accumulation on the efficient management of public finances. Observing fiscal sustainability in Croatia, Banić (2020) estimated the function of fiscal response applying the method of least squares (LS) in the period from 2002 to 2020 . Given the increase in the primary balance-GDP ratio due to the accumulation of public debt in Croatia, a positive reaction of fiscal policymakers is noticeable in response to the potential deterioration of public finances.

In contrast to findings of the positive reaction of fiscal policymakers to the accumulation of public debt, empirical research by Arčabić (2018) and Berti et al. (2016) indicates the absence of any reaction by fiscal policymakers. In more 
detail, Arčabić (2018) analyzed the sustainability of fiscal policy in the period from 2002 to 2017 in the EU-28 member states. The results of a dynamic panel system GMM estimator with common correlated effects indicate unsustainable fiscal policy at the EU level; fiscal policymakers do not increase the primary surplus due to the accumulation of public debt, with exceptions related to the EU-13 group and the sample of countries with a public debt-GDP ratio greater than $90 \%$. An analysis of fiscal sustainability in the EU-13 member states suggests dual results (Berti et al., 2016), for the fiscal response function was estimated by a vector error correction model (VECM) in the period from 1950 to 2013, the function for each country in the sample being estimated separately. The results show the absence of a fiscal response function with regard to the statistical insignificance of the public debt coefficient, while the example of France shows a fiscally unsustainable situation with regard to the negative sign of the lagged public debt coefficient in the model. However, by including in the model a dummy variable to identify the onset of the global financial crisis in 2009, the results point to a significant change in the behavior of fiscal policymakers. Moreover, for most countries in the selected group, the lagged public debt coefficient becomes positive and statistically significant. Consequently, research (Berti et al., 2016) emphasizes the importance of the dynamics of the relationship between the primary balance and public debt, which, in contrast to the assumed linear relationship in the aforementioned empirical research, could also be nonlinear.

Gosh et al. (2011) point out that the relationship between the budget balance and lagged public debt is not exclusively linear but depends on the level of debt, i.e., the public debt-GDP ratio, emphasizing that fiscal policymakers react only when the share of public debt in GDP exceeds a certain limit that may jeopardize fiscal sustainability. ${ }^{1}$ Also, significant accumulation of public debt can result in fiscal unsustainability despite the positive reaction of fiscal policymakers. Therefore, many studies assess the nonlinear function of the fiscal response, setting thresholds that indicate a change in the direction of fiscal policy. For example, Gosh et al. (2011) indicated the existence of a nonlinear relationship between the primary balance and lagged public debt in a sample of 23 developed economies in the period from 1970 to 2007. The relationship is approximated by the cubic function, where at low debt levels, the correlation between the primary balance and public debt does not exist, and if it does, then it is negligible. Furthermore, the panel analysis shows not only that the accumulation of public debt results in an increase in the primary balance but also that over time the reaction of fiscal policymakers tends to disappear and become completely absent at high, unsustainable levels of public debt. Cassou, Shadmani and Vázquez (2017) analyzed the fiscal sustainability of the USA in the period from 1955 to 2013, applying nonlinear threshold (TR) and Markov Switching (MS) models. An analysis on a short sample, from 1955 to 1995, indicates that fiscal policy is sustainable only in the switching model, given that the primary deficit is declining

\footnotetext{
${ }^{1}$ Reinhart and Rogoff (2010) also argue that public debt higher than $90 \%$ of GDP can have a negative effect on economic growth. However, this argument became controversial and was often rejected by subsequent research, see Arčabić et al. (2018).
} 
due to increasing debt. On a larger sample, from 1955 to 2013, the results point to fiscal sustainability exclusively in the Markov switching model and only during periods of economic expansion.

The behavior of fiscal policy can be countercyclical and procyclical. Tax revenues are sensitive to business cycles, i.e., they act as automatic stabilizers, and it is important to look at fiscal sustainability in the context of the cyclical nature of fiscal policy. The countercyclical policy is more desirable, and it can stimulate demand in recession by increasing government spending or reducing tax rates and do the opposite in times of economic expansion (Galí and Perotti, 2003). Arčabić (2018) determined the countercyclical behavior of fiscal policy in a sample of EU-28 countries using dynamic panel analysis. He showed a positive relationship between the output gap and the primary surplus, which can be explained as creating fiscal space to mitigate the negative effects of cycles in times of crisis. Dalić (2013) used panel data models to analyze the cyclical properties of government expenditure in the period 1999-2011 for Croatia and new member states that joined the EU in 2004 or later. Using the disaggregated approach, Dalić (2013) showed that the total general government expenditure and its main subcomponents (capital and current expenditure) behaved procyclically, while the social transfers behaved countercyclically. Regarding business cycle asymmetry, the results indicated procyclical behavior for total non-interest expenditure, capital expenditure, and non-wage government consumption in good and bad times, while for the other subcomponents, there is no strong statistical evidence of a difference in cyclical behavior during good and bad times. Cassou, Shadmani and Vázquez (2017) indicate the asymmetry of fiscal policy in the USA, given that fiscal policy in the threshold model is countercyclical during recessionary periods and less countercyclical during expansionary periods. On the other hand, fiscal policy is procyclical according to the Markov-switching model. Cassou, Shadmani and Vázquez (2017) explain the procyclicality of fiscal policy through empirical confirmation in research (Balassone, Francese and Zotteri, 2010) pointing out that, on the example of the EU, the increase in expenditures during the expansion is not accompanied by a decrease in expenditures during the recession, as is noticeable with revenues. Balassone, Francese and Zotteri (2010) stipulated the existence of cyclical asymmetry on a sample of EU-14 countries in the period 1970-2004, given that the budget balance deteriorates in a recession, but also that the balance does not improve during economic expansion. In the case of Croatia for the period 2003-2019, the results of Deskar Škrbić and Raos (2018) point to procyclical fiscal policy behavior during expansions and countercyclical fiscal policy behavior during recessions. The results of Deskar Škrbić and Grdović Gnip (2020) for the same period suggest the same conclusions regarding fiscal policy behavior during expansions, but not during recessions. The austerity measures implement, they suggest, resulted in procyclical fiscal policy behavior during recessionary periods. Furthermore, a significant contribution was made to the procyclical behavior of fiscal policy during expansion by expenditure growth, which is largely influenced by political cycles (Deskar Škrbić and Grdović Gnip, 2020). 


\subsection{DATA CONSTRUCTION AND SOURCES}

Our sample consists of quarterly data on the Croatian economy from 2000:1 to 2020:1. We decided to restrict our analysis to the period prior to the Covid-19 pandemic. The Covid-19 pandemic caused huge disturbances and created large outliers in the data, which could affect the results (see, for example, Lenza and Primiceri, 2020 on how to deal with such outliers). Extending the data to the most recent period would provide only three to four additional observations per series. Therefore, the analysis of the precrisis period is more reliable, and the results are not affected by huge outliers.

We use data on real GDP, public debt, and budget balance obtained from the Eurostat database. Real GDP and budget balance series are seasonally adjusted. In addition, we use the economic policy uncertainty index for Croatia developed by Sorić and Lolić (2017). The EPU index is based on the frequency of articles in leading Croatian newspapers (Jutarnji list, Večernji list, and 24 sata) and news websites (index.hr, Poslovni dnevnik, and Dnevnik.hr), spanning the period from January 2003 to the present, various terms related to economics, politics, and uncertainty being used for the construction of the index. The index is regularly updated by the authors and can be downloaded from Baker, Bloom, and Davis (2021).

We calculate cyclically adjusted primary balance (CAPB) in two steps. In the first step, we exclude interest payments from the budget balance to obtain the primary balance. Primary balance is calculated using the following equation: $p b_{t}=R_{t}-E_{t}+$ $i_{t} \times B_{t}$, where $R_{t}$ and $E_{t}$ are government revenues and expenditures, including interest payments. To exclude interest payments, we cancel them out by adding $i_{t} \times B_{t}$, term, which refers to interest payments on the existing debt. The interest payments series is from the Eurostat database. In the second step, the aggregate method is used to compute cyclically adjusted primary balance (see Švaljek, Vizek and Mervar, 2009). We estimate the primary balance elasticity with respect to output gap using the following equation: $p b_{t}=a+b \tilde{y}_{t}+e_{t}$. Primary balance in percent of GDP $\left(p b_{t}\right)$ is regressed on the output gap $\left(\tilde{y}_{t}\right)$ using OLS and the estimated coefficient $\hat{b}$ represents the elasticity. Then, CAPB is simply calculated as a difference between primary balance and the output gap multiplied by the estimated elasticity:

$$
c a p b_{t}=p b_{t}-\hat{b} \times \tilde{y}_{t}
$$

We use three estimates of output gap when calculating cyclically adjusted primary balance, univariate Hodrick and Prescott (HP) (1997) and Hamilton (2018) filters, and the bivariate decomposition based on the structural vector autoregression (SVAR) model.

Hodrick and Prescott (1997) decompose a time series into its trend and stationary components using the following optimization procedure:

$$
\min _{\tau}\left(\frac{1}{T} \sum_{t=1}^{T}\left(y_{t}-\tau_{t}\right)^{2}+\lambda \frac{1}{T} \sum_{t=2}^{T-1}\left[\left(\tau_{t+1}-\tau_{t}\right)-\left(\tau_{t}-\tau_{t-1}\right)\right]^{2}\right)
$$


where $y_{t}$ represents GDP, $T$ is the number of time series observations, and $\lambda$ is a smoothing parameter that we set to 1600 , which is considered common for quarterly data. The optimization process selects the $\tau_{t}$ series, which minimizes the sum of squares, thus giving the trend of the series, which is considered as potential output. We calculate the business cycle as a percentage deviation of GDP from the potential output. The HP filter is criticized in the literature for producing spurious cycles and for being imprecise at the beginning and the end of the sample (see Cogley and Nason, 1995; Hamilton, 2018).

Therefore, we use other filters as well. Hamilton (2018) proposes an alternative for the HP filter as a regression of $y_{t}$ series on a constant and four lags of $y_{t}$ two years ago. For our GDP series, we estimate the following equation:

$$
y_{t}=a_{0}+a_{1} y_{t-8}+a_{2} y_{t-9}+a_{3} y_{t-10}+a_{4} y_{t-11}+c_{t}
$$

Then, the residual $c_{t}$ from the equation (3) represents the business cycle.

The third output gap measure is obtained from the bivariate SVAR model proposed by Blanchard and Quah (1989), where supply and demand shocks are identified through long-run restrictions. The vector of endogenous variables contains GDP growth and unemployment, or $X_{t}^{\prime}=\left[\Delta y_{t}, u_{t}\right]$, and we estimate the following VAR model:

$$
A(L) X_{t}=e_{t}
$$

To identify supply and demand shocks, we impose the restriction that demand shocks do not affect GDP growth in the long run. Potential output is then calculated as a part of the GDP that is affected by supply shocks only. Historical decomposition is used to decompose GDP into its supply and demand components. As in the previous case, the output gap is calculated as a percent deviation of the GDP from the potential output. Such a measure of the output gap is also used in Furlanetto et al. (2020).

Figure 1 shows three output gap estimations and three corresponding cyclically adjusted primary balances. The shaded area represents the recession period in Croatia. It is obvious that the three methods for output gap calculation give different results (left panel of figure 1). Hamilton's filter is the most volatile, and provides a good description of the expansion prior to the global financial crisis (GFC) and of the sudden and deep recession starting in 2009. It also captures the increase in the Croatian output gap from 2014 onward. The HP filter is less volatile. It captures the expansion and potential overheating of the Croatian economy prior to the GFC, but the recession does not seem to be that deep in comparison to Hamilton's filter. In general, business cycle fluctuations are mostly close to the potential GDP according to the HP filter. Finally, the SVAR is not as volatile as the Hamilton filter but is describes business cycle fluctuations in Croatia as large swings. 
The SVAR model shows a deep recession starting in 2009, with the output gap constantly decreasing until the end of the recession in 2014. The recovery after 2014 is rather strong in comparison to the other two output gaps. Such large swings from the bivariate SVAR model capture changes not only in GDP but also in the labor market. A strong recovery after the crisis is more pronounced in the SVAR model because of a substantial decrease in the unemployment rate and overall positive trends in the labor market in Croatia after the GFC.

\section{Figure 1}

Three output gaps and three cyclically adjusted primary balances in percent of GDP

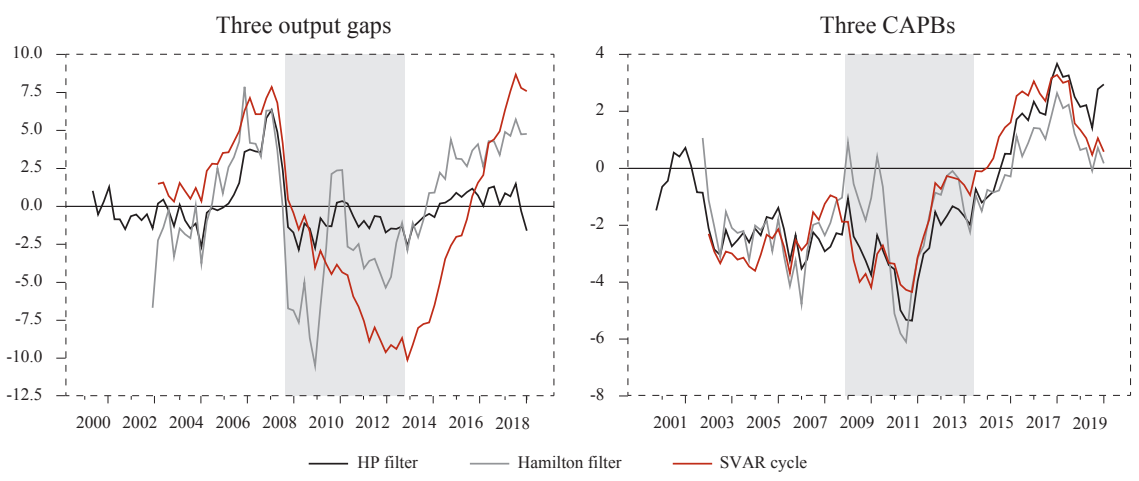

Note: Shaded areas represent the recession periods in Croatia.

The differences in output gap calculation reflect the cyclically adjusted primary balance as well, which is shown in the right panel in figure 1 . Nevertheless, all three balances show similar dynamics. The deficit was increasing, and it reached its maximum in 2011. After that, the policy measures by fiscal authorities turned the trend around, and the cyclically adjusted primary balance started to recover quickly. Soon after the end of the GFC in Croatia, all three measures show a surplus in the cyclically adjusted primary balance. The surplus reached its maximum in 2017 that corresponds with the end of the excessive deficit procedure in Croatia.

\subsection{METHODOLOGY}

Our fiscal response function can be described as the following OLS regression:

$$
c a p b_{t}=\alpha+\rho c a p b_{t-1}+\beta_{1} d_{t-1}+\beta_{2} \tilde{y}_{t-1}+\varepsilon_{t}
$$

where $c a p b_{t}$ is cyclically adjusted primary balance, $d_{t}$ is public debt, $\tilde{y}_{t}$ is a measure of the output gap, and $\varepsilon_{t}$ is the regression residual, which is assumed to be an iid error.

Fiscal policy is considered to be sustainable when the estimated coefficient next to lagged public debt is positive $\left(\beta_{1}>0\right)$. In that case, the government increases the cyclically adjusted primary balance by raising taxes or reducing spending as a response to higher indebtedness. This is considered sustainable behavior. 
On the other hand, fiscal policy is considered countercyclical when the estimated coefficient next to the output gap is positive $\left(\beta_{2}>0\right)$. As a response to the increase in the output gap, the government increases cyclically adjusted primary balance, thus smoothing the business cycle. We check the robustness of our results by changing the definition of the output gap between the HP, Hamilton, and SVAR gaps.

Our model includes richer dynamics than initially proposed by Bohn (1998) by adding lagged cyclically adjusted primary balance in the equation, which it is in line with (Cassou, Shadmani and Vázquez, 2017).

The main novelty of the paper is that we allow for the asymmetric behavior of fiscal policy. To capture such asymmetric behavior, we use two different nonlinear or switching models. We use the threshold autoregression model and Markov switching model with time-varying transition probabilities.

Our threshold autoregression model allows for two regimes depending on the endogenously selected threshold value $\theta$ :

$$
\operatorname{capb}_{t}=\left\{\begin{array}{lll}
\alpha_{1}+\rho_{1} \operatorname{capb}_{t-1}+\beta_{11} d_{t-1}+\beta_{12} \tilde{y}_{t-1}+\varepsilon_{t} & \text { if } & q_{t-d}^{T R}<\theta \\
\alpha_{2}+\rho_{2} \operatorname{capb}_{t-1}+\beta_{21} d_{t-1}+\beta_{22} \tilde{y}_{t-1}+\varepsilon_{t} & \text { if } & q_{t-d}^{T R} \geq \theta
\end{array}\right.
$$

where $q_{t}^{T R}$ is the threshold variable with the delay parameter $d=2$ which is used to account for the problem of endogeneity of the threshold variable. The model is estimated with OLS, and the threshold value $\theta$ is endogenously selected based on the Bai-Perron tests of $L+1$ vs. $L$ sequentially determined thresholds. We trimmed the highest and the lowest $10 \%$ of values prior to the threshold selection procedure.

We use the output gap as a threshold variable $q_{t}^{T R}$ to assess fiscal asymmetry, where the upper and lower regimes are typically interpreted as expansionary and recessionary regimes. They can also be related to good and bad economic times. We are looking for the asymmetric behavior between regimes. Asymmetric effects are found when $\beta_{11} \neq \beta_{21}$ which implies that fiscal sustainability depends on the regime, and when $\beta_{12} \neq \beta_{22}$ which implies that fiscal cyclicality depends on the regime.

We also use a two-state Markov switching model with transition probability dependent on the observable output gap (see Filardo, 1994), which is comparable to the threshold autoregression model. The Markov switching model is described as follows:

$$
\operatorname{capb}_{t}=\alpha\left(s_{t}\right)+\rho\left(s_{t}\right) \operatorname{capb}_{t-1}+\beta_{1}\left(s_{t}\right) d_{t-1}+\beta_{2}\left(s_{t}\right) \tilde{y}_{t-1}+\sigma\left(s_{t}\right) \varepsilon_{t}
$$


where $s_{t}$ is the state variable that allows for two unobservable regimes. All independent variables are allowed to switch between states. States are determined by the transition matrix and transition probabilities $p_{i j}$ given by:

$$
P=\left[\begin{array}{cc}
p_{11} & 1-p_{22} \\
1-p_{11} & p_{22}
\end{array}\right]
$$

Transitional probabilities $p_{i j}$ depend on the observable variable $q_{t}$ based on the logistic function of the following form:

$$
\begin{aligned}
& p_{11}\left(q_{t}\right)=\frac{\exp \left(o_{10}+o_{11} q_{t}\right)}{1+\exp \left(o_{10}+o_{11} q_{t}\right)}, \\
& p_{22}\left(q_{t}\right)=\frac{\exp \left(o_{20}+o_{21} q_{t}\right)}{1+\exp \left(o_{20}+o_{21} q_{t}\right)} .
\end{aligned}
$$

This type of model is proposed by Filardo (1994), and it is used in a similar application of public debt sustainability by Cassou, Shadmani and Vázquez (2017). Again, asymmetric behavior is found when coefficients $\beta_{1}$ or $\beta_{2}$ are different across regimes.

All the models are estimated with HAC standard errors based on the Newey-West window and four lags.

\section{RESULTS}

\subsection{FISCAL POLICY CYCLICALITY AND SUSTAINABILITY}

Figure 2 shows the results of a simple rolling regression based on equation (5). The left panel of figure 2 shows the results of fiscal sustainability by plotting the rolling window coefficient next to public debt. Positive coefficient signals fiscal sustainability. The right panel of figure 2 shows fiscal cyclicality, the positive relationship between CAPB and output gap signaling countercyclical fiscal policy. Blue lines are $95 \%$ confidence intervals. Each row in figure 2 shows the results for different output gap measures, which affect both CAPB calculation and the output gap. For simplicity, the shaded area represents the recession period in Croatia from 2009:1 to 2014:2, while two vertical red lines represent the beginning and the end of the excessive deficit procedure in Croatia, 2014:1 and 2017:2, respectively.

It is evident that fiscal sustainability varies over time, but the estimated coefficient is mostly positive and very low during the observed period. An exception is the beginning of the GFC between 2009 and 2012. However, the estimated confidence intervals show that the coefficient switches from positive to statistically equal to zero. The confidence intervals are especially wide at the beginning and the end of the period, and the coefficient is statistically insignificant most of the time.

However, a structural change is visible during and right after the EDP period, when the estimated coefficient is positive and increasing. At the same time, the 
estimated confidence intervals are unusually narrow, suggesting much lower standard errors. The reason for this is twofold. First, the substantial changes in the demarcation of the general government debt after Croatia's EU accession had an effect on debt sustainability. Furthermore, the EDP procedure motivated the policymakers to take firm measures with respect to public debt. Second, at the end of 2014, the recession in Croatia was over, and the GDP growth accelerated in 2015, thus decreasing the debt-to-GDP ratio.

Figure 2

Public debt sustainability and cyclicality, rolling window regression results

Sustainability:

Response of CAPB to debt

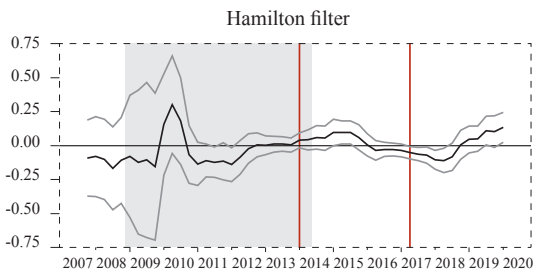

HP filter

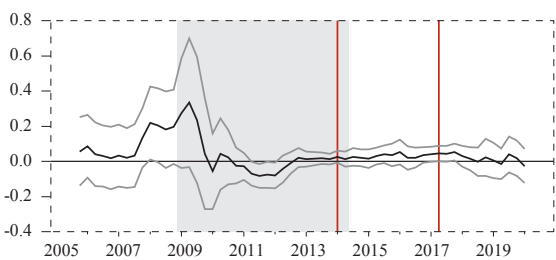

SVAR model

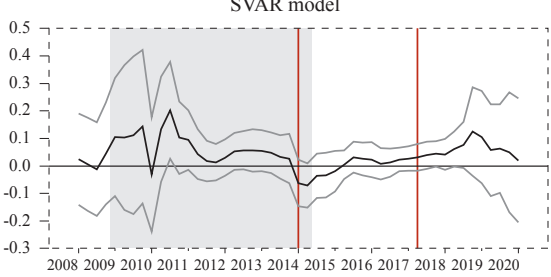

— Estimated coefficient
Cyclicality:

Response of CAPB to output gap

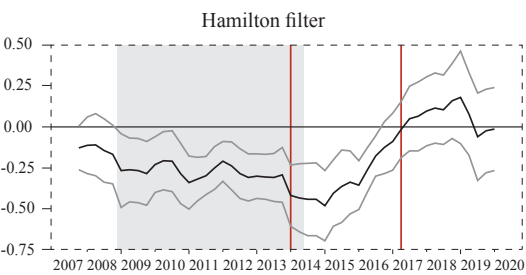

HP filter

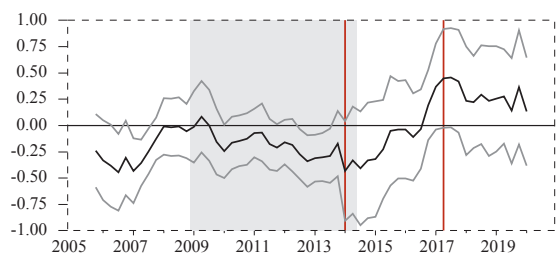

SVAR model

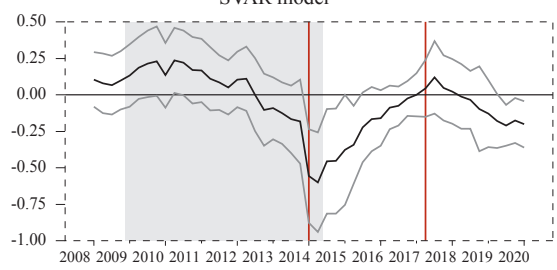

- $95 \%$ confidence interval

Note: Shaded areas represent the recession periods in Croatia. Vertical red lines indicate the beginning and the end of the excessive deficit procedure in Croatia (2014:1-2017:2). The rolling window size is 20 quarters (five years). Regression is estimated with HAC standard errors based on the Newey-West window and four lags.

The right hand panel of figure 2 shows fiscal cyclicality, which also shows evidence of structural change. Most of the time, fiscal policy is found to be procyclical when the Hamilton filter is observed and acyclical when the HP and SVAR model are observed. Only the magnitude of the estimated coefficient varies. A structural change can be observed during the EDP, as all three models show a substantial increase in the estimated coefficient. Such an increase indicates a change in the character of fiscal policy, going from procyclical to countercyclical. After the end of 
the EDP, all three models show a positive but insignificant response of CAPB to an increase in the output gap, suggesting that fiscal policy tends to be acyclical.

The initial results obtained from the rolling regression show a potential structural change in the fiscal response function, just as shown in Gosh et al. (2011). Such results motivate the use of more sophisticated models, such as threshold regression and Markov switching models, to assess the potential asymmetric behavior of fiscal policy over the business cycle.

Table 1 shows the results of the estimated linear and nonlinear models. We present different models in the first row. LM-HAM is a linear model in which the Hamilton filter is used to calculate the output gap and the cyclically adjusted primary balance. Furthermore, LM-HP represents a linear model in which the HP filter is used to calculate the output gap and the cyclically adjusted primary balance, while LM-SVAR represents the linear model in which we use the SVAR model to estimate the output gap and the cyclically adjusted primary balance. Accordingly, Threshold (TR) and Markov-switching (MS) models are presented in a similar way depending on which filter is applied to estimate the output gap and calculate the cyclically adjusted primary balance. In all cases, the threshold or switching variable in the TR and MS models is the output gap. We further test the asymmetry by checking the Wald test on the equality of coefficients in the two regimes. Results of the Wald test for debt to GDP ratio and the output gap are reported at the bottom of the table. Finally, we report test statistics for each model, including log-likelihood or R-squared, regimes volatilities for the MS models, serial correlation tests, and White's heteroskedasticity test.

From the aspect of public debt sustainability, linear models indicate the sustainable reaction of fiscal policymakers in Croatia, given that the increase in the public debt-GDP ratio results in an increase in the cyclically adjusted primary balanceGDP ratio. This is in line with the results of empirical research on fiscal sustainability in Croatia (Banić, 2020), in which the dependent variable is the primary balance. Furthermore, linear models indicate the countercyclical behavior of fiscal policy in Croatia with regard to the positive and significant sign of the lagged output gap. This result is robust to different measures of the output gap, except the SVAR model, which suggests acyclical fiscal policy, as indicated by the insignificant coefficient next to the output gap.

However, linear models do not provide information on the behavior of fiscal policy in different phases of business cycles. Therefore, in order to examine the existence of nonlinearity or asymmetry in the models, TR and MS models were estimated. 


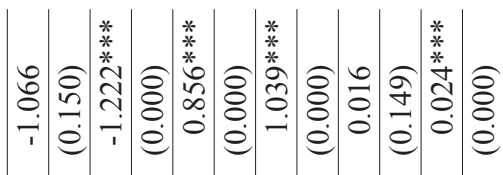

宓

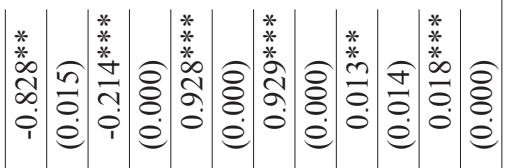

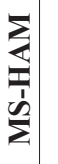

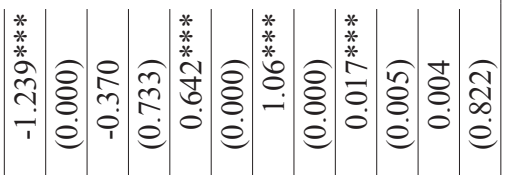

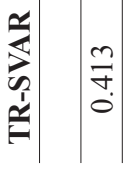

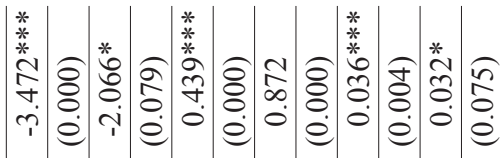

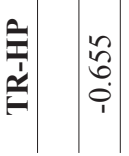

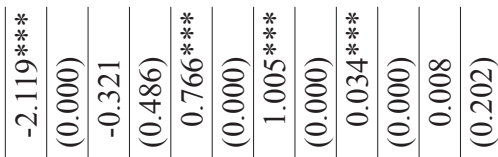

言|

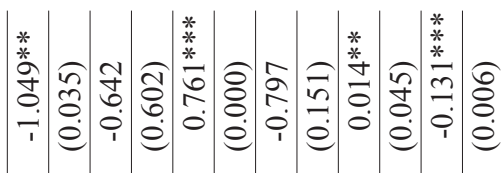

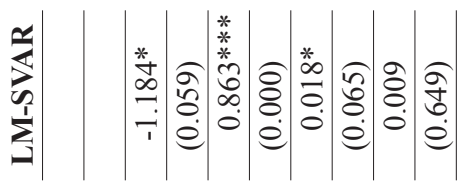

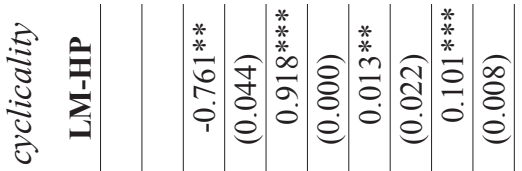

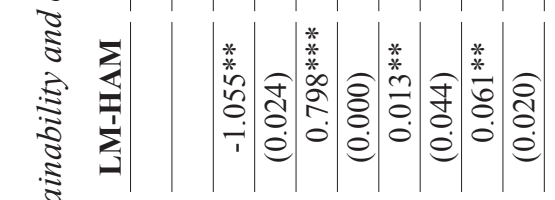

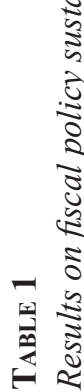

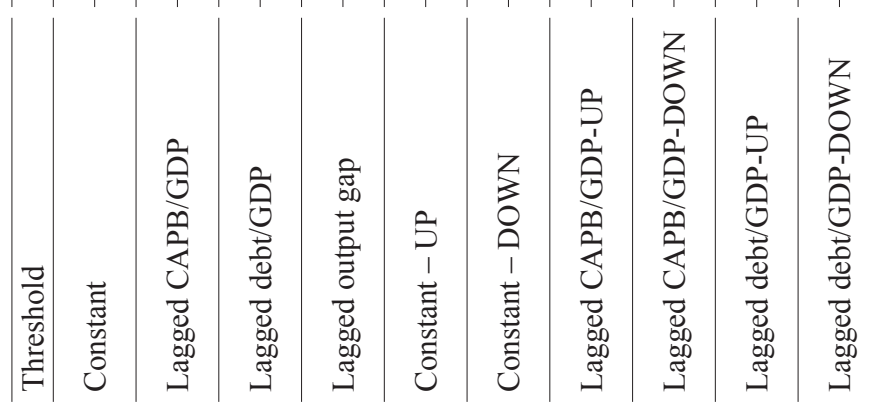




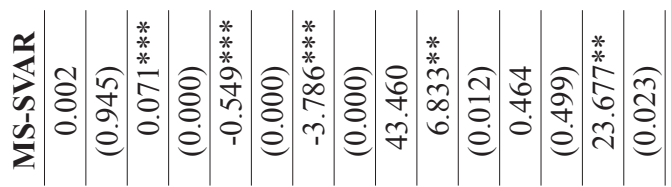

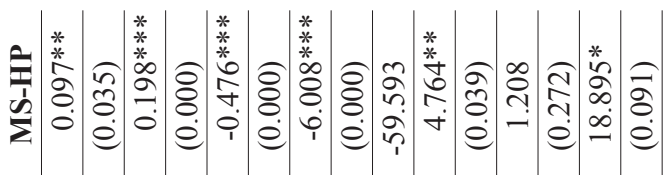

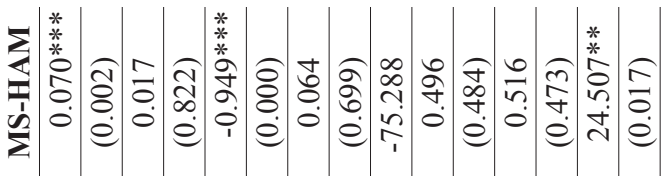

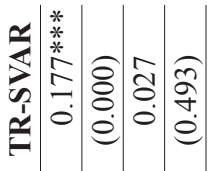

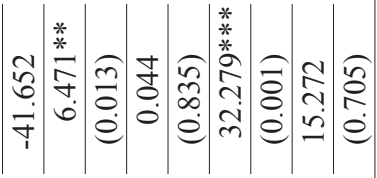

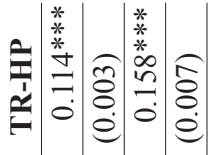

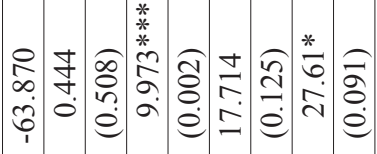

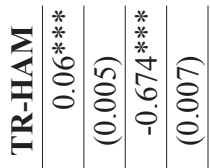

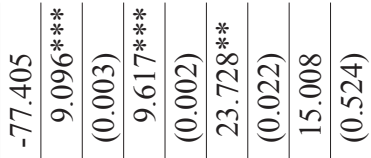

至|

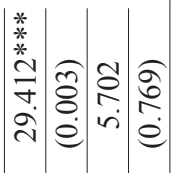

章

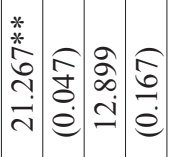

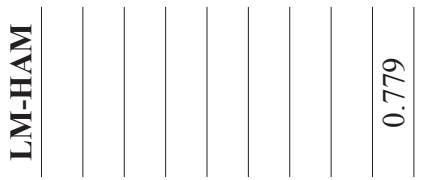

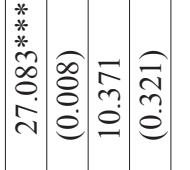

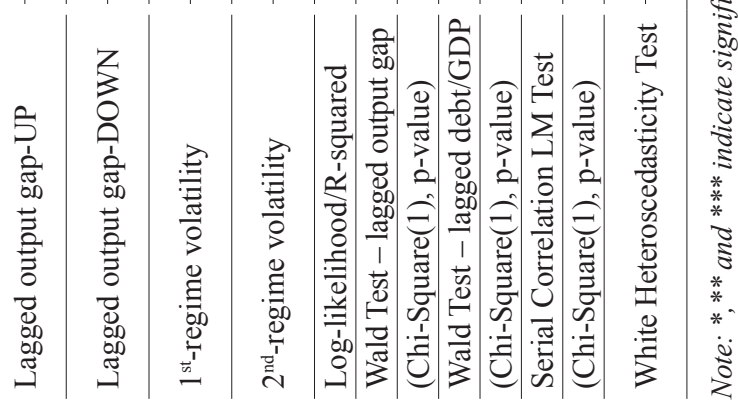
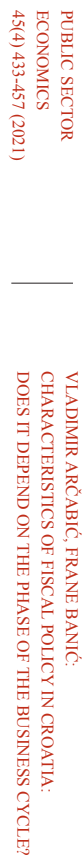

守

ఫ্

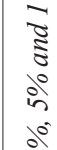

$\frac{2}{3}$ 
It is important to emphasize the distinction between the two regimes in the TR and MS models. Intuitively, for TR models, if the value of the output gap is above the threshold, the upper regime (UP) can be related to periods of expansion, and if the value of the output gap is below the threshold, the lower regime (DOWN) can be related to periods of recession. For MS models, the regimes are estimated depending on the probability of the unobserved state variable, with the regimes aligned with business cycles to relate them to expansion and recession periods. For simplicity, we still refer to them as upper and lower regimes (UP and DOWN) to relate with the TR model, even though the models differ. Cassou, Shadmani and Vázquez (2017) emphasize the difference between regime identification in TR and MS models, which may lead to different results. Namely, in TR models, the same level of innovation volatility above and below the threshold is assumed, while in MS models it is not, which is why the volatility in each regime is analyzed. In each of the endogenously identified regimes, we measure fiscal sustainability and cyclicality by analyzing how the cyclically adjusted primary balance responds to changes in lagged public debt and the output gap.

In figure 3, we show output gaps calculated with different filters together with the corresponding threshold values from the estimated models, depicted with a horizontal red line. The common reasoning is that the threshold should be close to zero. In that case, the upper regime corresponds with the expansion periods and positive output gaps, while the lower regime indicates negative output gaps and recessions. The estimated threshold values in the case of the HP filter and SVAR model indeed are close to zero; more precisely, they are -0.65 and 0.41 , respectively. The Hamilton filter yields a much lower threshold value of -3.35 . Nevertheless, in all three cases, there are enough observations in each regime for the proper inference.

\section{Figure 3}

Output gaps and estimated thresholds
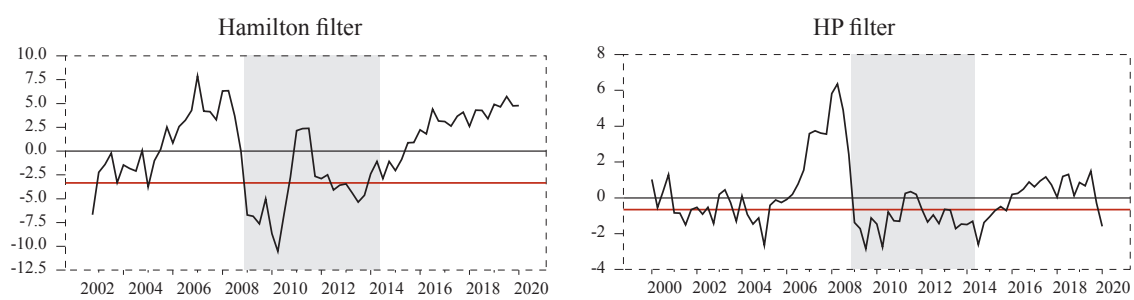

SVAR filter

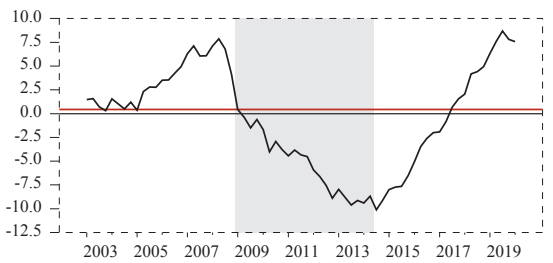

Note: Horizontal red line represents the estimated threshold value. Shaded areas represent the recession periods in Croatia. 
Our results suggest that fiscal policy in Croatia is mainly sustainable and countercyclical. Furthermore, we find only limited evidence of asymmetry in public debt sustainability and more pronounced evidence of asymmetric behavior when it comes to fiscal policy cyclicality. Out of six models, we find firm evidence that public debt sustainability depends on the business cycle in only two models. In four out of six models, fiscal policy cyclicality depends on the business cycle stage (expansion vs. recession).

When the upper regime results are observed, fiscal policy is both sustainable and countercyclical in all models except the MS-SVAR. Therefore, the findings of fiscal sustainability and countercyclical behavior of fiscal policy are fairly stable and certain in the upper regime, which corresponds with the expansionary phase of the business cycle.

The lower regime corresponds to the recessionary phase of the business cycle, and the results on sustainability and cyclicality are mixed. Still, in three out of six models, we find that fiscal policy is sustainable and countercyclical. Nevertheless, our result suggests higher model uncertainty in the lower regime.

The results of the TR-HAM, TR-HP, MS-HAM, and MS-SVAR models indicate asymmetry in the context of public debt sustainability, but the evidence is not entirely clear. Above the threshold, during expansionary periods, fiscal policymakers increase the cyclically adjusted primary balance due to the accumulation of lagged public debt, which is considered sustainable fiscal policy. In table 1, it is shown by positive coefficients next to lagged public debt. However, below the threshold, during recessions, either the accumulation of public debt results in a reduction of the cyclically adjusted primary balance, or the response is statistically equal to zero, which is not considered sustainable. However, the evidence is not completely robust, as the difference between the coefficients in the upper and lower regime is confirmed by the Wald test only for the TR-HAM and TR-HP models. In the case of the MS-SVAR model, we find the inverse response of cyclically adjusted primary balance, e.g., cyclically adjusted primary balance does not respond to an increase in public debt above the threshold, while the response is positive below the threshold.

Similarly, we find evidence of asymmetric behavior of fiscal policy cyclicality in the TR-HAM, TR-SVAR, MS-HAM, and MS-SVAR models. In the upper regime, fiscal policy is found to be countercyclical, while in the lower regime, it is either procyclical (TR-HAM) or acyclical. Again, the MS-SVAR model is an exception, showing the opposite characteristics between the regimes. The Wald test results confirm differences in estimated coefficients between two regimes in TR-HAM, TR-SVAR, MS-HP, and MS-SVAR.

We can observe that TR-HAM and MS-SVAR models stand out, both suggesting an asymmetric behavior of fiscal policy but with the opposite signs. It should be 
noted that the estimated threshold for the TR-HAM model is rather low, with a value of -3.35 , which can affect the results. Also, different volatility in regimes, as well as estimates of the output gap, may result in different assessments of fiscal policy behavior and sustainability. In the MS models, the volatility in the first regime, which refers to expansion, is about three to six times lower than in the second regime, which refers to recession.

This indicates that during good times, Croatian policymakers try to keep fiscal policy both sustainable and countercyclical, which is considered sound fiscal policy behavior. Below the threshold, in recession times, the characteristics of fiscal policy are not so clear, as our models provide different results. We find asymmetric behavior of public debt sustainability in only two out of six models. On the other hand, fiscal policy cyclicality depends on the phase of the business cycle in four out of six models. Therefore, we find some evidence of asymmetric behavior of fiscal policy cyclicality but only limited evidence of asymmetry in public debt sustainability.

\subsection{ROBUSTNESS CHECK}

We test the robustness of our results by including a growth rate of the index of economic policy uncertainty (EPU index) as a control variable in equations (5), (6), and (7). The economic policy uncertainty is recognized in the literature as a shock that has a significant but rather short and weak effect on both the real and financial sector in Croatia (Sorić and Lolić, 2017; Arčabić, 2015). Still, during the global financial crisis in Croatia from 2009 to 2014, economic policy uncertainty was very high, and we use it to capture its effects on fiscal policy. Deskar Škrbić and Raos (2018) emphasize the importance of policy influence in decision-making that may not be in line with medium- and long-term fiscal targets and, given that the EPU index may to some extent be of added value to assess the fiscal policy behavior.

The results of the linear models, which are presented in table 2, indicate fiscal policy sustainability, as well as the countercyclical behavior of fiscal policy; this is identical to the results of linear models in table 1. Furthermore, the LM-SVAR shows acyclical behavior of fiscal policy, which is identical to the previous results. EPU index is found to be positive and statistically significant only in the LM-HP model. 
章

豪

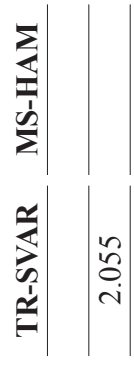

:

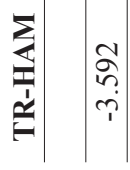

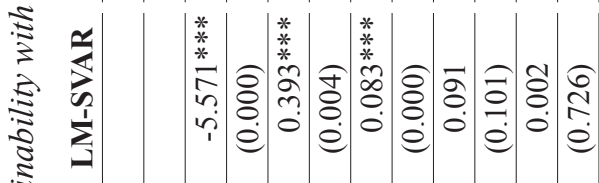

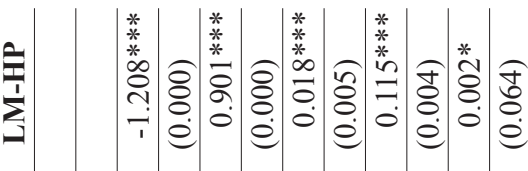

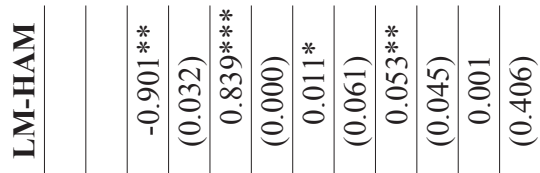

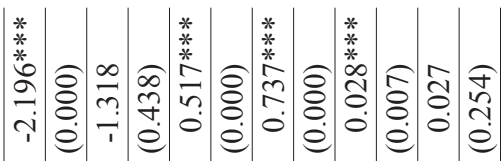

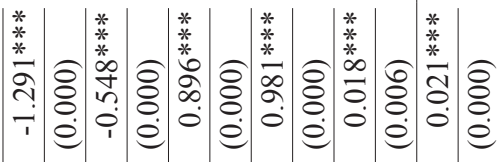

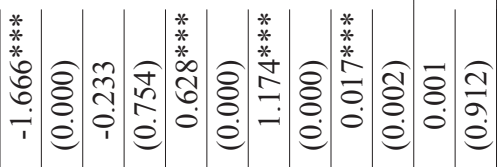

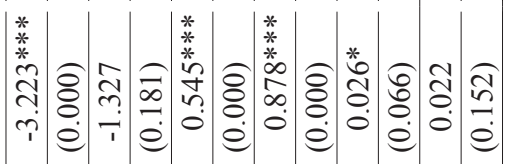

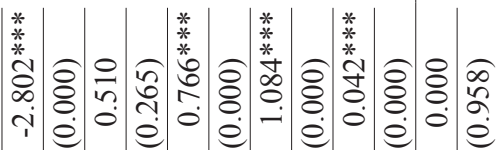

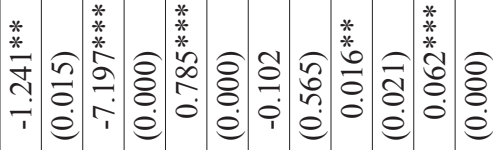


힌

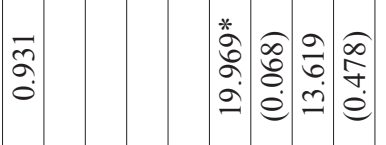

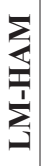

$\infty$
2
0
0

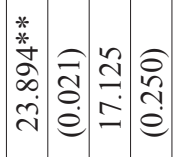

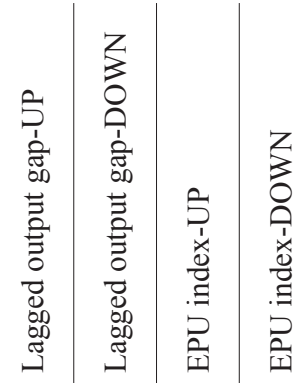

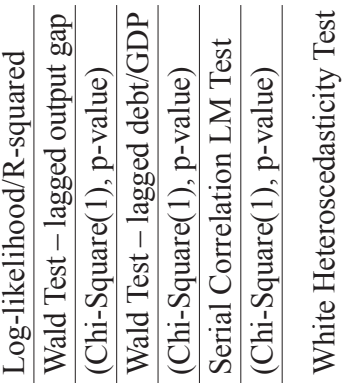

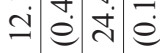
तें

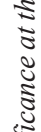


Public debt is again found to be sustainable in all models in the upper regime, which is related to the expansionary phase of the business cycle. We find evidence of asymmetric behavior of public debt sustainability in four out of six models. In TR-HP, TR-SVAR, MS-HAM, MS-SVAR, we find a positive response in the upper regime but a statistically insignificant response in the lower regime. No response of cyclically adjusted primary balance to increasing public debt is considered unsustainable. However, the Wald test confirms the difference in coefficients between regimes for only one model - TR-HP. Therefore, our results confirm only limited evidence of asymmetric behavior of public debt sustainability.

We find more evidence of asymmetry in fiscal policy cyclicality. In the upper regime, all the models show countercyclical fiscal policy, while in the lower regime, there is more uncertainty. We find procyclical behavior in the TR-HAM model and acyclical behavior in TR-SVAR and MS-HAM. Other models do not show signs of asymmetry. Again, we can confirm the findings from the benchmark model where some evidence of asymmetric behavior of fiscal policy cyclicality exists.

\subsection{DISCUSSION}

The absence of countercyclical behavior of a fiscal policy is noticeable in the research of Balassone, Francese and Zotteri (2010), which can be explained by the fact that procyclical behavior at the same time requires a focus on sustainable debt, which could accumulate significantly during a recession and consequently jeopardize fiscal rules. Also, regarding Croatia, fiscal policy behavior is mostly procyclical during both expansion and recession, according to Deskar-Škrbić and Grdović Gnip (2020), reflecting the impact of austerity measures during the recession and the impact of the political cycle on public expenditure growth. The results of our research are identical to those of Deskar-Škrbić and Grdović Gnip (2020) for the period of recessions but not for the period of expansion. Furthermore, some research results (Deskar-Škrbić and Raos, 2018) are opposite to ours, i.e., fiscal policy behavior is procyclical during expansion and countercyclical during recessions. There are many possible reasons why the results differ. Initially, the research by Deskar-Škrbić and Raos (2018) was conducted using descriptive methods. This allows for a precise determination of the fiscal policy behavior for each year, but by using this approach is not possible to assess the impact of the output gap on the cyclically adjusted primary balance. Also, different results potentially arise from the methodology of calculating the output gap and consequently the cyclically adjusted primary balance.

\section{CONCLUSION}

This paper aims to assess the behavior of fiscal policy and the sustainability of public debt during business cycles in Croatia by using Bohn's (1998) fiscal response function. We assess the robustness of our findings through different estimates of the output gap using univariate (Hamilton and HP) and multivariate (SVAR) models. Furthermore, to control for the effect of the business cycle, and in contrast to most research, the fiscal response function was estimated using the cyclically adjusted 
primary balance as a dependent variable. The choice of cyclically adjusted primary balance in relation to the primary or budget balance is meaningful in this research due to the empirical question of whether the behavior of fiscal policy depends on the business cycle, with the cyclically adjusted primary balance abstracting the impact of the cycle on budgetary categories. Therefore, the aforementioned framework is appropriate for the assessment of discretionary measures, which consequently determine the behavior of fiscal policymakers.

Since the results from the rolling regression signal a potential structural change in the fiscal response function, we used nonlinear threshold regression and Markov switching models to analyze potential fiscal policy asymmetry over the business cycle. In the nonlinear models, we use output gap as threshold/switching variable to assess fiscal asymmetry where the lower regime could be related to recessions while the upper regime could be related to expansions.

The results of linear models indicate public debt sustainability. Nonlinear models show only limited evidence of the asymmetric behavior of public debt sustainability. Four out of six nonlinear models signal asymmetric behavior in the context of public debt sustainability, but such asymmetry is confirmed by the Wald test in only two models. Therefore, fiscal policy is considered sustainable in the upper regime, while in the lower regime, results are less clear. To test the robustness, we included the growth rate of the economic and policy uncertainty index. The results of linear as well as nonlinear models are robust, but since the Wald test confirms the difference in public debt-GDP ratio coefficients between regimes for only one model, one can say that results confirm only limited evidence of the asymmetric behavior of public debt sustainability.

From the aspect of fiscal policy cyclicality, we find more evidence of the asymmetric behavior of fiscal policy. According to linear models, fiscal policy can be mostly characterized as countercyclical. Regarding the nonlinear models, the results indicate the asymmetric behavior of fiscal policy cyclicality in four out of six models. In other words, in the upper regime, fiscal policy behavior is countercyclical, while in the lower regime, it is either procyclical or acyclical, with the exception of one model with the opposite results. Also, the difference between the coefficients in the upper and lower regime is confirmed by the Wald test in three models, showing the opposite signs in models, which could be a result of different estimates of the output gap and threshold value as well as different volatility in Markov switching regimes. Regarding the robustness of results, in the upper regime, all the models indicate countercyclical fiscal policy, while in the lower regime, there is more uncertainty.

Overall, the results of empirical research mostly indicate that fiscal policy in Croatia is sustainable and countercyclical. Also, from the aspect of asymmetry, there is stronger evidence of asymmetry in fiscal policy cyclicality compared to public debt sustainability. The latter could reflect the dominance of discretionary 
measures in the lower regime, as well as policy makers' focus on public debt sustainability in the lower regime, which could be related to the excessive deficit procedure. Additionally, the empirical findings are highly important and favorable with respect to accession to the euro area, given the stability of public finances. In the context of research limitations, in subsequent research, an exogenously determined threshold value of zero output gap may be used instead of an endogenously determined threshold in order to identify the business cycle according to the author's assumptions. Also, the public debt to GDP ratio could be considered as a threshold or switching variable.

\section{Disclosure statement}

All authors state that they do not have any financial or other substantive conflict of interest. 
1. Arčabić, V. [et al.], 2018. Public debt and economic growth conundrum: Nonlinearity and inter-temporal relationship. Studies in Nonlinear Dynamics \& Econometrics, 22(1). https://doi.org/10.1515/snde-2016-0086

2. Arčabić, V., 2015. Djelovanje neizvjesnosti na bankarsko tržište u Republici Hrvatskoj. EFZG working paper series, (3), pp. 1-34.

3. Arčabić, V., 2018. Fiscal convergence and sustainability in the European Union. Public Sector Economics, 42(4), pp. 353-380. https://doi.org/10.3326/pse.42.4.1

4. Baker, S. R., Bloom, N. and Davis, S. J., 2021. Economic policy uncertainty index.

5. Balassone, F., Francese, M. and Zotteri, S., 2010. Cyclical asymmetry in fiscal variables in the EU. Empirica, 37(4), pp. 381-402. https://doi.org/10.1007/ s10663-009-9114-7

6. Banić, F., 2020. Stohastička analiza javnog duga: primjer Hrvatske. In: J. Tica and K. Bačić, eds. Ekonomska politika u 2021. godini - Hrvatska poslije pandemije, 28(10), pp. 291-320.

7. Berti, K. [et al.], 2016. Fiscal Reaction Functions for European Union Countries. European Economy Discussion Papers, No. 28.

8. Blanchard, O. J. and Quah, D., 1989. The Dynamic Effects of Aggregate Demand and Supply Disturbances. The American Economic Review, 79(4), pp. 655-673.

9. Bohn, H., 1998. The behavior of U.S. public debt and deficits. Quarterly Journal of Economics, 113(3), pp. 949-963. https://doi.org/10.1162/0033553985 55793

10. Cassou, S. P., Shadmani, H. and Vázquez, J., 2017. Fiscal policy asymmetries and the sustainability of US government debt revisited. Empirical economics, 53(3), pp. 1193-1215. https://doi.org/10.1007/s00181-016-1159-4

11. Checherita-Westphal, C. and Žd'árek, V., 2017. Fiscal reaction function and fiscal fatigue: evidence for the euro area. Working paper series, No. 2036.

12. Cogley, T. and Nason, J. M., 1995. Effects of the Hodrick-Prescott filter on trend and difference stationary time series Implications for business cycle research. Journal of Economic Dynamics and Control, 19(1-2), pp. 253-278. https://doi.org/10.1016/0165-1889(93)00781-x

13. Dalić, M., 2013. Cyclical properties of fiscal policy in new member states of the EU. Post-Communist Economies, 25(3), pp. 289-308. https://doi.org/10.1 080/14631377.2013.813144

14. Deskar-Škrbić, M. and Grdović Gnip, A., 2020. Obilježja fiskalne politike u Hrvatskoj. In: G. Družić [et al.], eds. Održivost javnih financija na putu u monetarnu uniju. Zagreb: HAZU: Ekonomski fakultet, pp. 121-139.

15. Deskar-Škrbić, M. and Raos, V., 2018. Karakter fiskalne politike i politička ekonomija fiskalne konsolidacije u Hrvatskoj u post-kriznom razdoblju. EFZG working paper series, No. 2.

16. Filardo, A. J., 1994. Business-cycle phases and their transitional dynamics. Journal of Business \& Economic Statistics, 12(3), pp. 299-308. https://doi. org/10.2307/1392086 
17. Furlanetto, F. [et al.], 2020. Norges Bank Output Gap Estimates: Forecasting Properties, Reliability and Cyclical Sensitivity. Norges Bank Research Working Paper, No. 7.

18. Galí, J. and Perotti, R., 2003. Fiscal policy and monetary integration in Europe. Economic Policy, 18(37), pp. 533-572. https://doi.org/10.1111/1468-0327.00115_1

19. Gosh, A. R. [et al.], 2011. Fiscal fatigue, fiscal space and debt sustainability in advanced economies. NBER Working Paper, No. 16782. https://doi.org/10.3386/ w16782

20. Hamilton, J. D., 2018. Why you should never use the Hodrick-Prescott filter. Review of Economics and Statistics, 100(5), pp. 831-843. https://doi.org/10.1162/ rest_a_00706

21. Hodrick, R. J. and Prescott, E. C., 1997. Postwar US business cycles: an empirical investigation. Journal of Money, Credit, and Banking, 29(1), pp. 1-16. https://doi.org/10.2307/2953682

22. Lenza, M. and Primiceri, G. E., 2020. How to Estimate a VAR after March 2020. NBER Working paper, No. 27771. https://doi.org/10.3386/w27771

23. Piergallini, A. and Postigliola, M., 2012. Fiscal policy and public debt dynamics in Italy, 1861-2009. CEIS Research Paper, No. 248. https://doi.org/10.2139/ Ssrn. 2118748

24. Reinhart, C. M. and Rogoff, K. S., 2010. Growth in a Time of Debt. American economic review, 100(2), pp. 573-78. https://doi.org/10.1257/aer.100.2.573

25. Sorić, P. and Lolić, I., 2017. Economic uncertainty and its impact on the Croatian economy. Public Sector Economics, 41(4), pp. 443-477. https://doi. org/10.3326/pse.41.4.3

26. Švaljek, S., Vizek, M. and Mervar, A., 2009. Ciklički prilagođeni proračunski saldo: primjer Hrvatske. Radni materijali EIZ-a, (1), pp. 5-51. 